\title{
Comparing Neem Seed Oil with Calcium Chloride and Fungicides for Controlling Postharvest Apple Decay
}

\author{
Harold E. Moline ${ }^{1}$ and James C. Locke ${ }^{2}$ \\ Beltsville Agricultural Research Center, Agricultural Research Service, \\ U.S. Department of Agriculture, Beltsville, MD 20705
}

Additional index words. storage, ethylene, Malus domestica

\begin{abstract}
The antifungal properties of a hydrophobic neem (Azadirachta indica A. Juss.) seed extract (clarified neem oil) were tested against three postharvest apple (Malus domestica Borkh.) pathogens- Botrytis cinerea (pers.) ex Fr. (gray mold), Penicillium expansum Thom. (blue mold rot), and Glomerella cingulata (Ston.) Spauld. \& Schrenk. (bitter rot). The antifungal activity of neem seed oil also was compared to that of $\mathrm{CaCl}_{2}$. $\mathrm{A}$ $2 \%$ aqueous emulsion of the clarified neem seed oil was moderately fungicidal to $B$. cinerea and $G$. cingulata in inoculated fruit, but bad little activity against $P$. expansum. Ethylene production was reduced $80 \%$ in fruit dipped in $2 \%$ neem seed oil compared to wounded, inoculated controls. Neem seed oil was as effective an antifungal agent as $\mathrm{CaCl}_{2}$, but the effects of the two combined were not additive.
\end{abstract}

Recently, using fungicides to control postharvest decay of fruit and vegetables has been restricted severely. Many compounds are being removed from use, rather than undergoing the stringent tests required for re-registration. The challenge to reduce postharvest losses by means other than synthetic fungicides led us to investigate the use of a natural material reported to have antimicrobial activity (Kher and Chaurasia, 1977; Locke, 1986, 1990).

Treating fruit with $\mathrm{CaCl}_{2}$ has extended storage life and reduced postharvest decay (Conway et al., 1992). However, it is difficult to infiltrate enough $\mathrm{Ca}$ into fruit to eliminate decay without severely damaging the fruit (Conway and Sams, 1987). Using $\mathrm{CaCl}_{2}$ combined with low concentrations of fungicides (Moline, 1990), heat treatments (Klein, 1989), biological control agents (McLaughlin et al., 1990), or other natural compounds that may enhance natural resistance to decay, while controlling incipient infections that can reduce fruit quality (Arras, 1988; Kher and Chaurasia, 1977; Mukherjee and Bisqau, 1984), may be a more practical approach.

Humans have known that neem seed and leaf extracts are beneficial since the fourth century (National Research Council, 1992). The insecticidal properties of neem seeds' triterpenoid-containing extracts are well docu-

\footnotetext{
Received for publication 3 Aug. 1992. Accepted for publication 26 Feb. 1993. We thank J.F. Walter of W.R. Grace \& Co., Columbia, Md., for supplying the sample of clarified neem seed oil and reviewing the manuscript. Mention of a trademark, warranty, proprietary product, or vendor does not constitute a guarantee by the U.S. Dept. of Agriculture and does not imply its approval to the exclusion of other products or vendors that also maybe suitable. The cost of publishing this paper was defrayed in part by the payment of page charges. Under postal regulations, this paper therefore must be hereby marked advertisement solely to indicate this fact. ${ }^{1}$ Horticultural Crops Quality Laboratory. ${ }^{2}$ Florist and Nursery Crops Laboratory.
}

mented (Koul et al., 1990). Recent research (Koul et al., 1990; Locke, 1986, 1990) has shown that clarified neem seed oil, a residue of the extraction of insecticidal compounds from neem seeds, also has insecticidal and fungicidal properties.

The objectives of this study were to evaluate the effects of clarified neem seed oil (W.R. Grace \& CO., Columbia, Md.) combined with $\mathrm{CaCl}_{2}$ on stored apples and to compare these effects with other postharvest fungicide treatments used to maintain fruit quality and reduce decay during storage.

'Golden Delicious' apples were harvested at the preclimacteric stage (as indicated by $\mathrm{CO}_{2}$ and ethylene production patterns) from the research orchard at the Beltsville (Md.) Agricultural Research Center. Fruit were randomized and stored at $0 \mathrm{C}$ for 4 months.

To determine the effect of treatment on decay, lots of 30 fruit per treatment were wound-inoculated on four sides as described by Conway and Sams (1987) with Penicillium expansum, Botrytis cinerea, or Glomerella cingulata. Three lots each were treated by dipping them in $1 \%$ or $2 \%$ aqueous neem seed oil, methyl $\{1-[($ butylamino)carbonyl $]-1 H$ benzimidazol-2-yl carbamate (benomyl) at $1000 \mathrm{mg}$ a.i./liter, 3a,4,7,7a-tetrahydro-2[(trichloromethyl)thiol]-1 $H$-isoindole$1,3(2 \mathrm{H})$ - dione (captan) at $500 \mathrm{mg}$ a.i./liter, or 1 - [2-(2,4-dichlorophenyl)-2 - (2propenyloxy)ethyl]-1 $H$ - imidazole (imazalil) at $750 \mathrm{mg}$ a.i./liter after inoculating them with the pathogens. Lots receiving $\mathrm{CaCl}_{2}$ were pressure-infiltrated with $2 \% \mathrm{CaCl}_{2}$ and dried for $2 \mathrm{~h}$ before being inoculated with the pathogens. The lots receiving $\mathrm{CaCl}_{2}$ plus neem seed oil were pressure-infiltrated with $\mathrm{CaCl}_{2}$ as indicated, inoculated, dried, and dipped in $1 \%$ neem seed oil, dried again, and stored at $20 \mathrm{C}$. Three more 30-fruit lots were inoculated with the fungi, dried, and stored (inoculated controls). Three more 30-fruit lots were used as nontreated controls to measure ethylene.
After 7 days at 20C, firmness was determined for 10 fruit from each treatment using a penetrometer (Magnus-Taylor; D. Ballauf Manufacturing Co., Laurel, Md.) with an 11.1$\mathrm{mm}$ tip, which penetrated $8.0 \mathrm{~mm}$ deep. Because this measurement was destructive, these fruit were discarded after being measured. The remaining fruit were rated for decay after 7 , 10 , and 14 days of storage at $20 \mathrm{C}$ by measuring the diameter of decayed areas surrounding the puncture wounds. The fruit inoculated with $G$. cingulata were rated for decay after 7, 14, and 21 days at $20 \mathrm{C}$ because of the slower growth of this pathogen.

Ethylene production and respiration rate of 10 fruit from each treatment were monitored for 10 days at $20 \mathrm{C}$ using an automated system (Watada and Massie, 1981).

Data were tested using analysis of variance and Duncan's multiple range test. Experiments were repeated three times with similar results; therefore, only the results of the first experiment are shown.

There was considerable variability in the growth rate of the three fungi on punctureinoculated apples, as measured by the increase in lesion diameter. Botrytis cinerea and $P$. expansum are faster-growing wound pathogens than is $G$. cingulata, but all three fungi can cause serious postharvest losses in stored fruit. Efficacy of treatments to control decay reflected the aggressiveness of the three pathogens. Fourteen days after inoculating nontreated fruit with $B$. cinerea and $P$. expansum, average lesion diameter was 54 and $59 \mathrm{~mm}$, respectively. Lesion diameter on controls inoculated with $G$. cingulata was 42 $\mathrm{mm}$ after 21 days.

Neem seed oil applied as a dip to puncture-inoculated fruit significantly reduced decay caused by $B$. cinerea and $G$. cingulata (Table 1). Mean lesion diameter on $B$. cinerea -inoculated fruit dipped in $2 \%$ neem seed oil was $32 \mathrm{~mm}$ after 14 days. Twenty-one days after being inoculated with $G$. cingulata, fruit treated with $2 \%$ neem seed oil had a mean lesion diameter of $19 \mathrm{~mm}$. Neem seed oil did not significantly affect decay caused by $P$. expansum (Table 1).

Calcium chloride infiltration also significantly reduced decay caused by $B$. cinerea $(44 \%)$ and G. cingulata (81\%). The combination of $1 \%$ neem oil and $2 \% \mathrm{CaCl}_{2}$ did not differ significantly from $\mathrm{CaCl}_{2}$ only (Table 1).

Neem seed oil also significantly affected wound ethylene production. Fruit dipped in neem seed oil after wound-inoculation produced $80 \%$ less ethylene than wound-inoculated controls. Fruit dipped in $2 \%$ neem seed oil produced no more ethylene than nonwounded, noninoculated controls. Ethylene production was steady over the 7-day storage period at 20C, a result indicating that fruit were in a postclimacteric status. Representative data from day 7 are shown (Table 2).

A check as to whether the reduced ethylene could be caused by active metabolic inhibition or simply by a gas exchange barrier in the fruit revealed that neem seed oil acted as a passive barrier to ethylene. Sliced apples treated with neem seed oil produced only slightly less 
Table 1. Percentage of 'Golden Delicious' apples infected after being wound-inoculated with one of three pathogens and infiltrated with $\mathrm{CaCl}_{2}$ or treated with neem seed oil or one of three fungicides.

\begin{tabular}{|c|c|c|c|}
\hline \multirow[b]{2}{*}{ Treatment ${ }^{y}$} & \multicolumn{3}{|c|}{ Pathogen $^{2}$} \\
\hline & $\begin{array}{l}\text { Botrytis } \\
\text { cinerea }\end{array}$ & $\begin{array}{l}\text { Penicillium } \\
\text { expansum }\end{array}$ & $\begin{array}{c}\text { Glomerella } \\
\text { cingulata }\end{array}$ \\
\hline \multicolumn{4}{|l|}{ Neem seed oil } \\
\hline None $^{\mathrm{x}}$ (control) & $100 \mathrm{a}^{\mathrm{w}}$ & $100 \mathrm{a}$ & $100 \mathrm{a}$ \\
\hline $1 \%$ & $71 \mathrm{~b}$ & $92 \mathrm{a}$ & $67 \mathrm{c}$ \\
\hline $2 \%$ & $59 \mathrm{~b}$ & $86 \mathrm{ab}$ & $46 \mathrm{~d}$ \\
\hline $1 \%+2 \% \mathrm{CaCl}_{2}^{\mathrm{v}}$ & $53 \mathrm{~b}$ & $91 \mathrm{a}$ & $15 \mathrm{f}$ \\
\hline $\mathrm{CaCl}_{2}, 2 \%$ & $56 \mathrm{~b}$ & $93 \mathrm{a}$ & $19 \mathrm{ef}$ \\
\hline \multicolumn{4}{|l|}{ Fungicide } \\
\hline Benomyl (1000 mg.liter $\left.{ }^{-1}\right)$ & $7 c$ & $5 \mathrm{c}$ & $65 \mathrm{c}$ \\
\hline Captan (500 mg.liter $\left.{ }^{-1}\right)$ & $0 \mathrm{c}$ & $79 \mathrm{~b}$ & $81 \mathrm{~b}$ \\
\hline Imazalil (750 mg.liter ${ }^{-1}$ ) & $\ldots$ & $0 \mathrm{c}$ & $24 \mathrm{e}$ \\
\hline
\end{tabular}

${ }^{x}$ Fruit were puncture-wounded, inoculated by dipping them in a suspension of $10^{4}$ fungal spores $/ \mathrm{ml}$ water, and allowed to dry for $1 \mathrm{~h}$ before being treated. Data represent percentage of wounds infected after each treatment.

${ }^{y}$ Fruit were treated after inoculation by dipping them in water suspensions for $2 \mathrm{~min}$, dried, and stored on fiber trays covered with perforated plastic bags.

"Average lesion diameter was $54 \mathrm{~mm}$ for $B$. cinerea and $59 \mathrm{~mm}$ for $P$. expansum 14 days after inoculation and $42 \mathrm{~mm}$ for $G$. cingulata 21 days after inoculation.

"Mean separation within columns by Duncan's multiple range test, $P \leq 0.05$.

${ }^{\circ}$ Calcium-treated fruit were pressure-infiltrated at $69 \mathrm{kPa}$ for $2 \mathrm{~min}$ and dried before being inoculated with fungi.

ethylene than slices dipped in sterile distilled water as controls (Table 2). Neem seed oil probably plugged the small puncture wounds made in the fruit before inoculation, thus, internal $\mathrm{O}_{2}$ was lowered and internal $\mathrm{CO}_{2}$ was raised. This activity could have inhibited ethylene production. Neem seed oil also may have reduced botrytis decay by providing a protective barrier on the fruit surface, as has been suggested by its protective effect against several foliar rust and powdery mildew diseases (Locke, 1990). Ethylene has stimulated the germination of some postharvest pathogens (El-Kazzas et al., 1983); however, its effects on B. cinerea vary (El-Kazzas et al., 1983; Kepczynski and Kepczynski, 1977). We doubt that neem seed oil actively inhibited ethylene production in damaged fruit.

Neem seed oil did not affect fruit firmness. Calcium chloride enhanced fruit firmness as described previously (Conway and Sams, 1987).

The reduced decay in wound-inoculated fruit is a result of moderate antifungal action by neem seed oil. Although this antifungal action is not sufficient to protect completely wound-inoculated fruit, it reduced decay as much as $50 \%$. Under storage conditions in which natural infection causes decay, this reduction may be sufficient to protect fruit. Using neem seed oil as a natural fruit coating with moderate antifungal activity merits further investigation. The antifungal action of neem seed oil also has been demonstrated with soilborne fungi (Locke, 1986; Singh et al., 1980a). The fungitoxic action of neem seed oil has been attributed to its sulfur content (Singh et al., 1980b). Although applying higher concentrations of neem seed oil may further enhance its antifungal activity, concentrations $>2 \%$ leave a sticky residue on the fruit surface (unpublished data) that may reduce consumer acceptance.

\section{Literature Cited}

Arras, G. 1988. Antimicrobial activity of various essential oils against some citrus fruit disease agents, p. 787-793. In: R. Goren and K. Mendel (eds.). Proceedings of the Sixth International Citrus Congress. vol. 2. Balaban Publishers, Philadelphia.

Conway, W.S. and C.E. Sams. 1987. The effects of postharvest infiltration of calcium, magnesium, or strontium on decay, firmness, respiration, and ethylene production in apples. J. Amer. Soc. Hort. Sci. 112:300-303.

Conway, W.S., C.E. Sams, R.G. McGuire, and A Kelman. 1992. Calcium treatment of apples and potatoes to reduce postharvest decay. Plant Dis. 76:329-334.

El-Kazzas, M.K., N.F. Sommer, and A.A. Kadar. 1983. Ethylene effects on in vitro and in vivo growth of certain postharvest fruit-infecting fungi. Phytopathology 73:99-1001.

Kepczynski, J. and E. Kepczynski. 1977. Effect of ethylene on germination of fungal spores causing fruit rot. Fruit Sci. Rpt. (Skeirniewice) 4:3135 .

Kher, A. and S.C. Chaurasia. 1977. Anti-fungal activity of essential oils of three medicinal plants. Indian Drugs 46:41-42.

Klein, J.D. 1989. Ethylene biosynthesis in heat-treated apples, p. 181-189. In: H. Clijsters, M. De Proft, R. Marcelle, and M. Van Poucke
Table 2. 'Golden Delicious' apple whole-fruit ethylene production after treatment plus 7 days of storage at $20 \mathrm{C}$ compared to slices stored for 5 days at $20 \mathrm{C}$.

\begin{tabular}{lcc}
\hline \hline & \multicolumn{2}{c}{$\begin{array}{c}\text { Ethylene production } \\
\left(\mu \mathrm{l}_{\mathrm{kg}}^{-1} \cdot \mathrm{h}^{-1}\right)\end{array}$} \\
\cline { 2 - 3 } Treatment & Whole fruit & Slices $^{2}$ \\
\hline $\begin{array}{c}\text { Inoculated } \\
\text { control }\end{array}$ & $44 \mathrm{a}^{\mathrm{y}}$ & $\cdots$ \\
Neem & $31 \mathrm{~b}$ & $132 \mathrm{~b}$ \\
$1 \%$ & $14 \mathrm{c}$ & $122 \mathrm{bc}$ \\
$2 \%$ & $16 \mathrm{c}$ & $109 \mathrm{c}$ \\
$\mathrm{CaCl}_{2}, 2 \%$ & & \\
Noninoculated & $13 \mathrm{c}$ & $152 \mathrm{a}$ \\
$\quad$ control &
\end{tabular}

${ }^{2}$ Whole fruit were incubated for 7 days and slices for 5 days at $20 \mathrm{C}$ after treatment.

${ }^{y}$ Fruit were wound-inoculated with Botrytis cinerea by dipping punctured fruit in a suspension containing $10^{4}$ fungal spores $/ \mathrm{ml}$ water.

${ }^{x}$ Mean separation within columns by Duncan's multiple range test, $P \leq 0.05$.

(eds.). Biochemical and physiological aspects of ethylene production in lower and higher plants. Kluwer Academic Publishing, Dodrecht, The Netherlands.

Koul, O., M.B. Isman, and C.M. Ketkar. 1990 Properties and uses of neem, Azadirachta indica. Can. J. Bot. 68: 1-11.

Locke, J.C. 1986. In vitro fungitoxicity of an ethanolic extract of neem seed on Rhizoctonia solani and Fusarium oxysporum. Phytopathology 76:1129.

Locke, J.C. 1990. Activity of extracted neem seed oil against fungal plant pathogens, p. 132-136. In: J.C. Locke and R.H. Lawson. (eds.). Neem's potential in pest management programs. Proc. U.S. Dept. Agr. Neem Workshop. U.S. Dept. Agr., Agr. Res. Serv. ARS-86.

McLaughlin, R.J., M.E. Wisniewski, C.L. Wilson, and E. Chalutz. 1990. Effect of inoculum concentration and salt solutions on biological control of postharvest diseases of apple with Candida, sp. Phytopathology 80:456-461.

Moline, H.E. 1990. The use of postharvest calcium-fungicide applications to control apple storage diseases. Phytopathology 80:974.

Mukherjee, N. and P. Bisqas. 1984. Control of plant diseases with plant oils: Their problems and prospects. Indian Agr. 28: 145-151.

National Research Council. 1992. Neem: A tree for solving global problems. National Academy Press, Washington, D.C.

Singh, N., R. Nath, S.P. Singh, and R.P. Koh. 1980a. Clinical evaluation of antihelmintic activity of Melia azadirachia. Antiseptic 77:739-741.

Singh, U. P., H.B. Singh, and R.B. Singh. 1980b. The fungicidal effect of neem (Azadirachta indica) extracts on some soil-borne pathogens of gram (Cicer arietinum). Mycologia 72:10771093.

Watada, A.E. and D.R. Massie. 1981. A compact automated system for measuring $\mathrm{CO}_{2}$ and $\mathrm{C}_{2} \mathrm{H}_{4}$ evolution by harvested horticultural crops. HortScience 16:39-41. 